\title{
South Africa Telecom Market Analysis
}

\author{
Yufei Gao \\ Roedean Senior School, Parktown, Johannesburg, South Africa \\ Email: Ygao@roedeanschool.co.za
}

How to cite this paper: Gao, Y. F. (2021) South Africa Telecom Market Analysis. American Journal of Industrial and Business Management, 11, 1113-1127. https://doi.org/10.4236/ajibm.2021.1111067

Received: September 27, 2021

Accepted: November 27, 2021

Published: November 30, 2021

Copyright (C) 2021 by author(s) and Scientific Research Publishing Inc. This work is licensed under the Creative Commons Attribution-NonCommercial International License (CC BY-NC 4.0). http://creativecommons.org/licenses/by-nc/4.0/ (c) (i) (5) Open Access

\begin{abstract}
This report analyzes the telecom market in South Africa (SA) by first comparing the SA telecom market with other countries, and then, by using the trends found in other countries' telecom markets as a benchmark, determining how SA subscribers can anticipate better pricing in the future.
\end{abstract}

\section{Keywords}

Telecom Operators, Wireless, Fixed Network, Data, Airtime

\section{Background}

South Africa, as the second-largest country in Africa, has a population of 58.56 million and a GDP in 2020 of $\$ 301$ billion, ranking $39^{\text {th }}$ in the world. South Africa and Nigeria often act as benchmarks for other African countries.

Telecommunication service requirements in SA have grown rapidly in the past five years. Recently, data requirements have grown especially quickly because of new technologies (like Artificial Intelligence and the Internet of Things) and the COVID-19 pandemic. The two key markets within the SA Telecom market are "to Business" (2B) and "to Consumers" (2C). Each of the two key markets has two main telecom infrastructures: wireless \& fixed network. Together, they currently serve about 99M wireless subscribers in South Africa, meaning that every subscriber has on average 1.7 SIM cards (in Figure 1), excluding fixed network services' subscribers (such as xDSL and fiber). Later, when we analyze fixed network services (xDSL and fiber) separately (in Table 1), it will be seen that the coverage rate of South African operators is higher than those of operators in China and Germany.

South Africa's macroenvironment indicates that growth is gradually slowing. At the same time, an analysis of subscriber trends suggests that, while consumption in subscribers increased, willingness to pay has decreased. These two trends are likely due to the impact that COVID-19 had on the subscribers' incomes. 
Table 1. Number of connections.

\begin{tabular}{ccccccccccc}
\hline Connectivity Services & 2014 & 2015 & 2016 & 2017 & 2018 & 2019 & 2020 & 2021 & AGR (\%), 2017-2021 \\
\hline & & \multicolumn{7}{c}{ Busines Cnnections (Thousands) } \\
\hline Internet Access - xDSL & 404.34 & 392.48 & 346.35 & 322.95 & 299.48 & 257.71 & 200.71 & 138.33 & $-19.1 \%$ \\
Intemet Acces- Ftb & 38.32 & 63.35 & 96.89 & 140.18 & 200.18 & 280.71 & 383.40 & 498.01 & $37.3 \%$ \\
${ }^{*}$ Others & 93.20 & 92.78 & 94.78 & 99.33 & 105.17 & 112.12 & 119.12 & 125.73 & $6.1 \%$ \\
Total Connections & 535.86 & 548.61 & 538.02 & 562.46 & 604.83 & 650.55 & 703.23 & 762.07 & $7.9 \%$ \\
\hline Internet Access - xDSL & 577.63 & 618.87 & 629.68 & 579.48 & 541.12 & 468.96 & 384.28 & 282.60 & $-16.4 \%$ \\
Intemnet Access - Fth & 13.07 & 36.10 & 81.75 & 173.66 & 280.57 & 436.82 & 620.37 & 749.08 & $44.1 \%$ \\
${ }^{*}$ Others & 340.54 & 279.99 & 307.37 & 581.22 & 1129.99 & 1360.53 & 1526.23 & 1580.52 & $28.4 \%$ \\
Total Connections & 931.24 & 934.97 & 1018.80 & 1334.37 & 1951.68 & 2266.32 & 2530.88 & 2612.20 & $18.3 \%$
\end{tabular}

*IDC: Others including Dedicated Internet Access (DIA), Fixed Wireless Access (FWA), and Satellite (SAT).

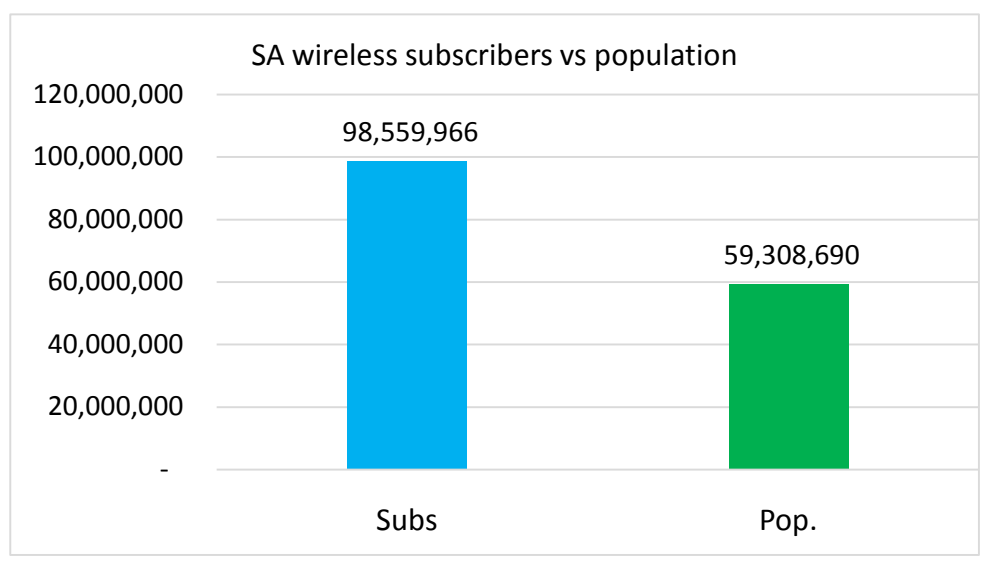

Figure 1. SA Wireless subscribers vs population. ${ }^{\star}$ Number of subscribers: Operator's finance report. ${ }^{\star}$ Population: the World Bank.

Because of these trends, wireless operators in South Africa are facing a huge challenge in growing the Telecom market. However, due to data services becoming more common and popular in SA, communication service demands are still growing. I therefore forecast that wireless subscribers will continue growing, though they will not increase as quickly as they have over the past three years; fixed network subscribers' growth will remain constant or slightly decline due to the growth of wireless subscribers, which will take over some of the market from the fixed network.

The next question is whether the average unit price is cheaper or more expensive in South Africa than it is in other countries. The table compares South Africa's unit prices to those of Germany and China to compare with South Africa (in Table 2, Figures 2(a)-(c)), and it clearly indicates that South Africa's market unit price is cheaper than that of Germany but more expensive than that of China. The unit price was influenced by macro-economic status and operators' operation capability. Generally, the unit price in SA is reasonable and unit prices will likely continue to decline. 
Table 2. South Africa's unit prices vs Germany \& China.

\begin{tabular}{|c|c|c|c|c|c|c|}
\hline Country & $\begin{array}{c}\text { GDP per } \\
\text { capita USD }\end{array}$ & Operator & Data (GB) & Package Price & $\begin{array}{c}\text { Unit Price } \\
\text { per GB }\end{array}$ & $\begin{array}{l}\text { Unit Price } \\
\text { USD/GB }\end{array}$ \\
\hline \multirow{4}{*}{ SA } & \multirow{4}{*}{6001.40} & Cell C & 100 & ZAR 199.00 & 1.99 & 0.145 \\
\hline & & MTN & 120 & ZAR 269.00 & 2.24 & 0.163 \\
\hline & & Vodacom & 100 & ZAR 899.00 & 8.99 & 0.655 \\
\hline & & Telkom & 80 & ZAR 248.00 & 3.10 & 0.226 \\
\hline \multirow{4}{*}{ Germany } & \multirow{4}{*}{$46,445.25$} & Congstar & 200 & EUR 45.00 & 0.23 & 0.274 \\
\hline & & Lycamobile & 50 & EUR 79.99 & 1.60 & 1.951 \\
\hline & & DT & 20 & EUR 20.00 & 1.00 & 1.220 \\
\hline & & Vodafone & 16 & EUR 29.95 & 1.87 & 2.283 \\
\hline \multirow{3}{*}{ China } & \multirow{3}{*}{$10,261.68$} & China Mobile & 200 & CNY 29.00 & 0.15 & 0.023 \\
\hline & & China Telecom & 200 & CNY 19.00 & 0.10 & 0.015 \\
\hline & & China Unicom & 125 & CNY 36.00 & 0.29 & 0.045 \\
\hline
\end{tabular}

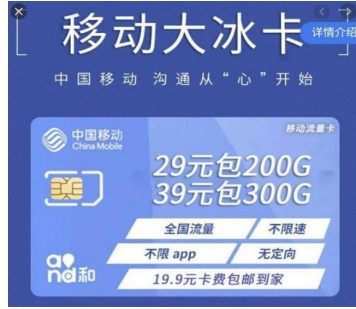

(a)

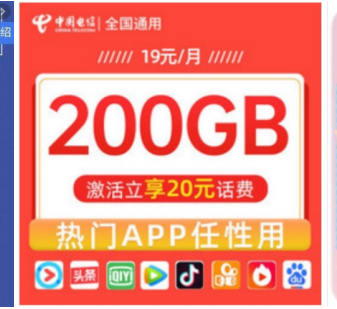

(b)

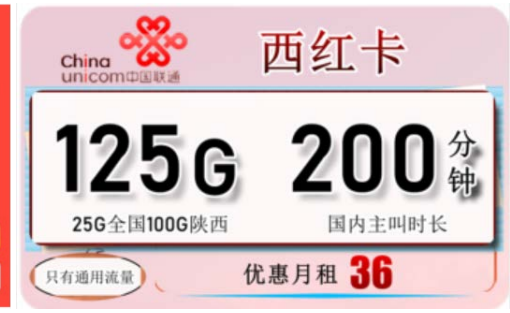

(c)

Figure 2. *Data source: operators’ AD (online/offline).

\section{Wireless Market Analysis}

\subsection{C Subscribers (Wireless Market)}

Due to South Africa's economic status, the number of small to middle enterprises (SMEs) is much larger than the number of big enterprises. Our research has shown that some SMEs use consumers' packages with WIFI routers, sharing data services among staff to reduce costs. This means that our $2 \mathrm{C}$ subscribers' analysis also includes some demands/subscribers from SME.

When we investigated the wireless $2 \mathrm{C}$ market, we found that the numbers of prepaid subscribers is considerably larger than the number of postpaid subscribers (in Table 3), likely because of South Africa's current economic situation in $\mathrm{SA}$, in which many lower-income people can only afford prepaid services, as the postpaid service package is often more expensive and needs to be paid monthly. Although postpaid subscribers produce more profit, the large number of prepaid subscriber forces operators to focus on this market segment.

The operators have to drop unit/package prices to keep their market share and number of subscribers. Their price changes are listed as below for reference (in Figures 3(a)-(c)). 
Table 3. Prepaid subscribers vs postpaid subscribers in SA.

\begin{tabular}{cccc}
\hline Subscribers & \multicolumn{3}{c}{2020} \\
\cline { 2 - 4 } (Thousand) & VDC & MTN & Telkom \\
\hline Total & 41,312 & 28,890 & 11,995 \\
Prepaid & 35,231 & 22,804 & 9432 \\
Postpaid & 6081 & 6086 & 2563 \\
\hline
\end{tabular}

\begin{tabular}{|c|c|c|c|}
\hline $\begin{array}{l}\text { Bundle } \\
\text { size }\end{array}$ & $\begin{array}{c}\text { Current } \\
\text { price }\end{array}$ & $\begin{array}{l}\text { Old } \\
\text { price }\end{array}$ & Change \\
\hline $30 \mathrm{MB}$ & - & R12 & $\begin{array}{c}\text { Remove } \\
\mathrm{d}\end{array}$ \\
\hline $50 \mathrm{MB}$ & R12 & $\begin{array}{l}\text { R25 for } \\
55 \mathrm{MB}\end{array}$ & $-47.2 \%$ \\
\hline $200 \mathrm{MB}$ & $\mathrm{R} 29$ & $\begin{array}{l}\text { R29 for } \\
100 M B\end{array}$ & $-50.0 \%$ \\
\hline $350 \mathrm{MB}$ & R49 & $\begin{array}{l}\text { R63 for } \\
250 M B\end{array}$ & $-44.4 \%$ \\
\hline $500 \mathrm{MB}$ & R69 & R99 & $-30.3 \%$ \\
\hline $1 \mathrm{~GB}$ & R85 & R149 & $-43.0 \%$ \\
\hline $2 \mathrm{~GB}$ & R159 & R249 & $-36.1 \%$ \\
\hline $3 G B$ & R229 & R299 & $-23.4 \%$ \\
\hline $5 G B$ & R349 & R399 & $-12.5 \%$ \\
\hline
\end{tabular}

(a) $12.5 \%$ and $50 \%$ decrease
MTN prepaid data price cuts since 2019

Bundle Current 2019 Change

$\begin{array}{cccc}\text { size } & \text { price } & \text { price } & \text { Change } \\ 100 \mathrm{MB} & \text { R20 } & \text { R29 } & -31.0 \%\end{array}$

150MB R29 R39 $-25.6 \%$

200MB R39 - NeW

350MB R60 300MB $-14.3 \%$

$\begin{array}{llll} & & \text { for R60 } & \\ 500 M B & \text { R75 } & 600 \mathrm{MB} & -9.1 \%\end{array}$

$\begin{array}{llll}750 M B & \text { R89 } & \text { for R99 } & -25 \\ & & -25.8 \%\end{array}$

$1 G B \quad R 99-R 149-33.6 \%$

1.5GB $\quad$ R149 $\quad$ R189 $-21.2 \%$

2GB R189 - $\quad$ New

3GB R229 - New

6GB R399 - New

(b) $6 \%$ and $33.6 \%$ decrease

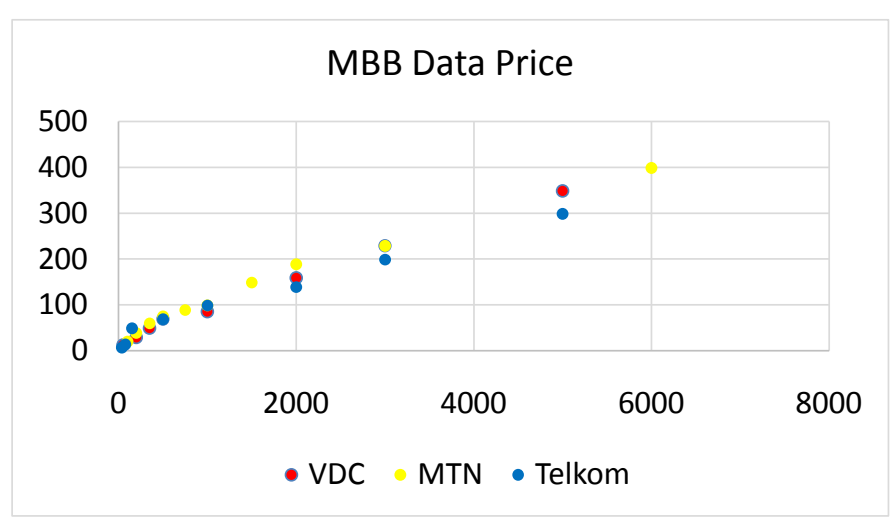

(c)

Figure 3. (a) VDC prepaid data price; (b) MTN prepaid data price; (c) MBB data price. * Data source: finance statement of operators and their online/offline advertisement.

\subsection{B Customers (Wireless Market)}

2B customers normally take advantage of MIFI routers (inserting a sim card as uplink) to provide data services for their staff. The substantial difference in size between $2 \mathrm{~B}$ and $2 \mathrm{C}$ comes from the data package policy.

All of the operators are becoming more aggressive in their advertising strategies, launching many attractive Wireless Home broadband offers in an attempt to gain more market share in the South African Telecom market (in Figures $4(a)-(d))$. 


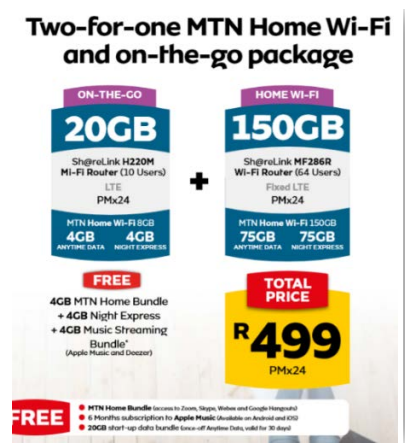

(a)

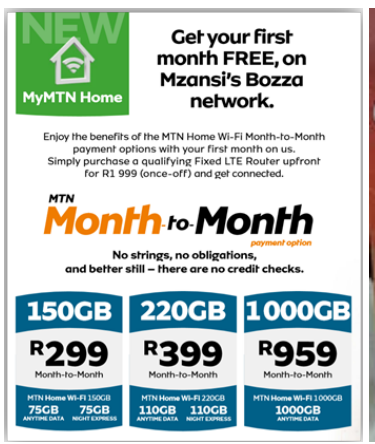

(b)

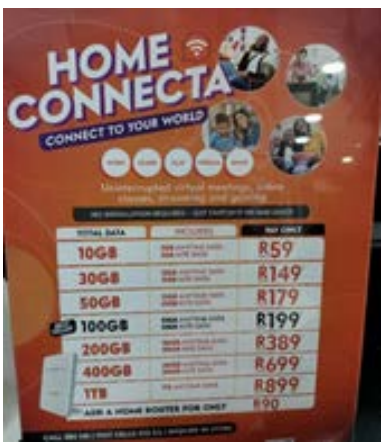

(c)

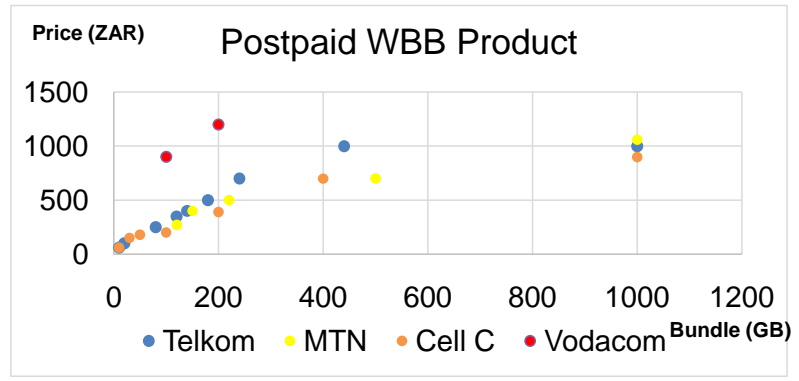

(d)

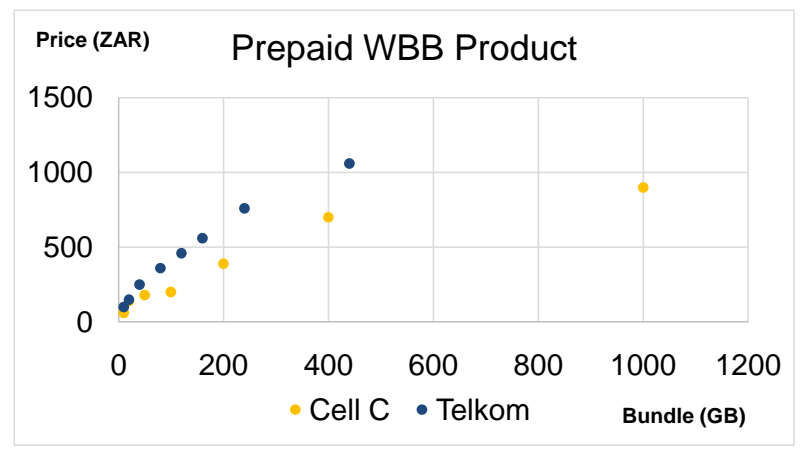

(e)

Figure 4. (a) MTN offers; (b) Telkom offers; (c) CellC offers; (d) Postpaid WBB products; (e) Prepaid WBB products. ${ }^{*}$ Data source: online/offline advertisement of operators.

\subsection{Operators' Competition (Wireless Market)}

As previously mentioned in Background Introduction, each person in South Africa has an average of 1.7 SIM cards, so operators compete vigorously in the sector that generates high and stable profits: the $2 \mathrm{C}$ postpaid subscribers. After CellC sold their postpaid subscribers to VDC, the competition of postpaid subscribers is now between VDC and MTN, as other operators have only won a small number of postpaid subscribers. Most of the competition occurred in the prepaid subscriber market due to the current postpaid market situation in SA.

$>$ Online market competition:

Due to COVID-19, online sales channels now play an important role; consequently, nearly all of the operators have invested money and labor to develop their online market (in Figures 5(a)-(d)). 


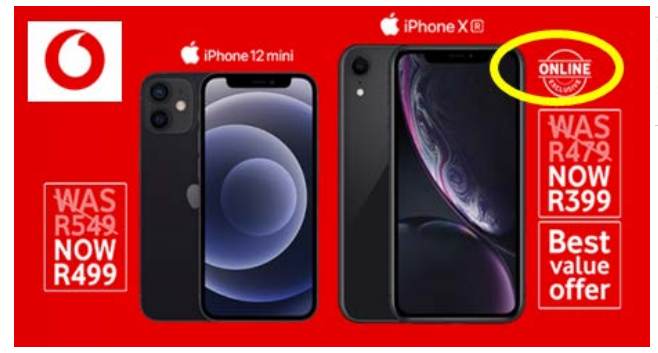

(a)

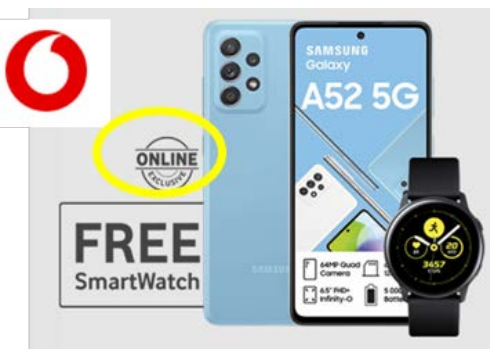

(b)

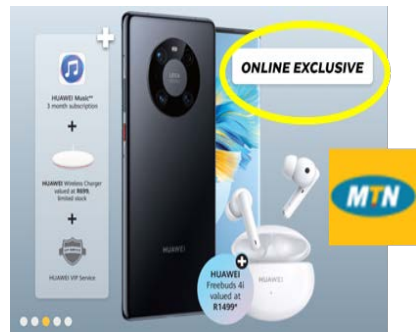

(c)

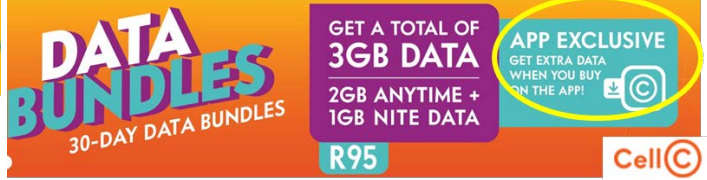

(d)

Figure 5. (a) VDC offer; (b) VDC offer; (c) MTN offer; (d) CellC offer.

\section{Price competition:}

Our investigation shows that CellC has recently started a price war (in Table 4), which we believe will increase the number of requirements from subscribers.

A comparison of the trends our market research has identified in South Africa to those in Europe and East Asia shows that operators have tried to decrease the unit price per Giga in order to enlarge the consumer market. The price war will enlarge the demand pipeline and concurrently benefit both operators and subscribers.

\subsection{New Services Drivers (Wireless Market)}

The demand for wireless data services is growing in both the $2 \mathrm{~B}$ and $2 \mathrm{C}$ markets. In Europe and East Asia, Artificial Intelligence (AI), Internet of Things (IoT) and other new services are placing new demands on the big data pipeline (in Figure 6(a), Figure 6(b)). AI will be a revolutionary feat of computer science, and is likely to become a core component of all modern software over the coming years. The strengthening link between AI and Big Data will produce a huge demand on data services when it becomes more developed in the Ecosystem/Industry. This trend will be also layer apply in South Africa as SMEs and big companies continue to grow.

Data bundle services in the wireless market, such as online shopping and online education, have grown explosively in Europe, the USA, and East Asia.

My research suggests that almost all operators have benefited from the impact of COVID-19; the only difference will be the percentage in which the use of airtime/data services will grow among the different countries and operators. 


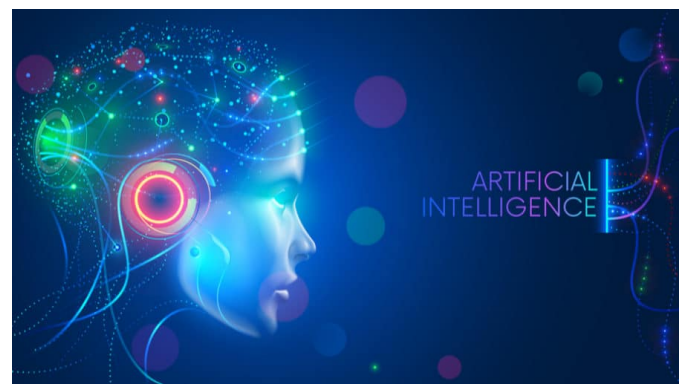

(a)

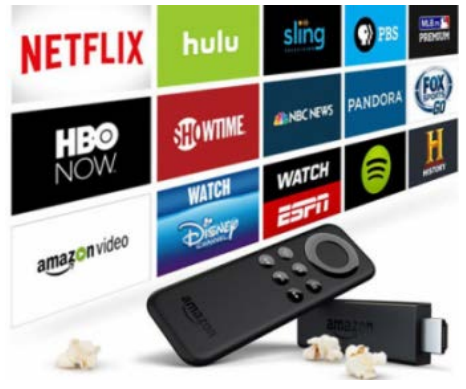

(b)

Figure 6. (a) AI; (b) Video service.

Table 4. Price war analysis.

\begin{tabular}{ccccccc}
\hline Operator & $\begin{array}{c}\text { Anytime } \\
(\mathrm{GB})\end{array}$ & $\begin{array}{c}\text { Night } \\
\text { Data } \\
(\mathrm{GB})\end{array}$ & $\begin{array}{c}\text { Application } \\
(\mathrm{GB})\end{array}$ & $\begin{array}{c}\text { Total } \\
\text { Data } \\
(\mathrm{GB})\end{array}$ & $\begin{array}{c}\text { Package } \\
\text { Price } \\
\text { ZAR }\end{array}$ & $\begin{array}{c}\text { Unit Price } \\
\text { ZAR/GB }\end{array}$ \\
\hline SA Cell C & 50 & 50 & 0 & 100 & 199 & 1.99 \\
MTN SA & 50 & 50 & 20 & 120 & 269 & 2.24 \\
Vodacom SA & 50 & 50 & 0 & 100 & 899 & 8.99 \\
SA Telkom & 40 & 40 & 0 & 80 & 248 & 3.10 \\
\hline
\end{tabular}

* Data source: online/offline advertisement of operators.

\section{Fixed Network Market}

\subsection{C Subscribers (Fixed Network Market)}

Our research into the data services of the South African telecommunication market report (IDC*) shows that the percentage of data kept increasing while the percentage of airtime kept decreasing. In particular, between 2014 and 2016, fixed networks (FTTx) connections grew at a compound annual growth rate (CAGR) of 70\%, albeit from a low base. We predict that FTTx connections will continue to grow, while XDSL connections will experience a sharp decline.

Open Access policy has created a new market opportunity, which has eroded the value of traditional operators. Investing in open access fiber not only delivers macroeconomic benefits to this country but also provides better customer experiences to end-users. The South African Telecom ecosystem has experienced investment from several multi-party entities including energy companies, municipalities, real estate companies, and infrastructure investors. Cost synergies of up to $25 \%$ were created by using the existing utilities' infrastructure. Since retail operators have access to the same underlying wholesale fiber infrastructure, the take-up rate and overall operational economics have improved.

As open-access fiber gains acceptance, traditional fixed network operators need to adjust their fixed broadband strategies accordingly. Traditionally, incumbents resisted partnering with open access fiber entities by accelerating their fiber rollout, whether fiber to the home (FTTH) or fiber to the curb (FTTC). Recently, however, some incumbents are trying to gain higher market shares by 
acquiring open-access fiber or finding partners through wholesale and whole-buy agreements. Challenger operators are proactively forging partnerships with open access fiber entities, whilst aggressively trying to expand their fixed broadband offerings to gain market share in what was traditionally the incumbents' turf. Non-telcos, especially energy and utility companies, are seeing new business opportunities in operating open access fiber in selected markets as well as fiber infrastructure.

According to our research, South Africa's fixed broadband speeds are on average 85\% lower than global players (in Figure 7(a), Figure 7(b)).

\section{Global Fixed Broadband Speed test (Mbps)}

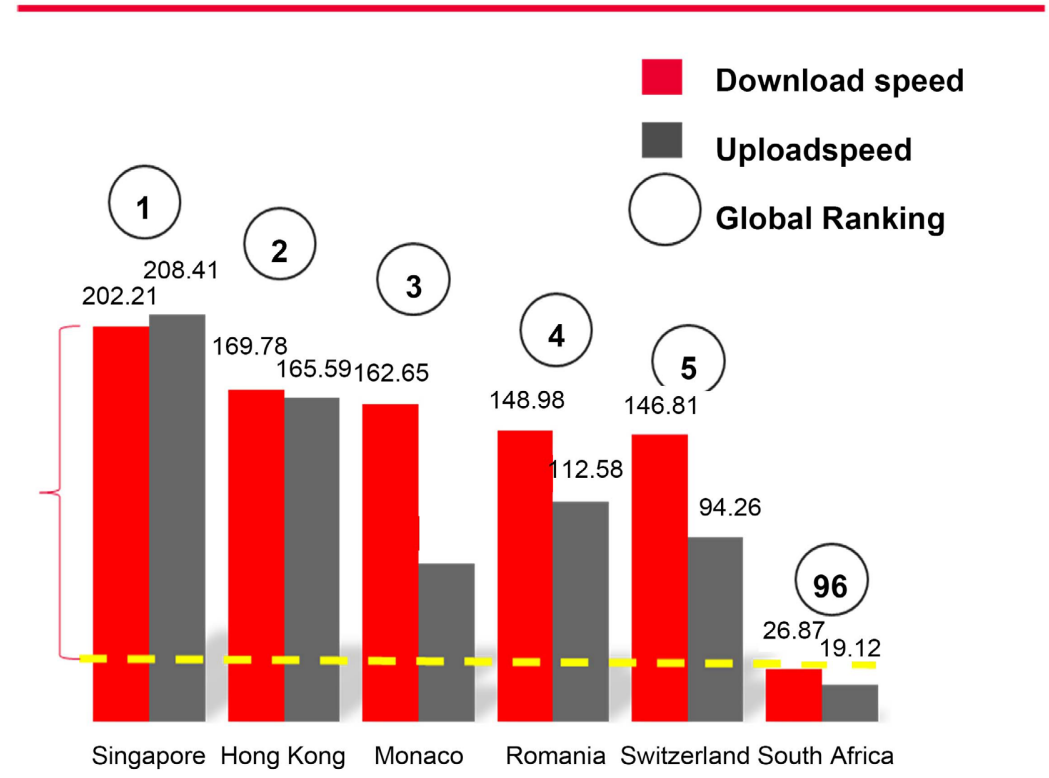

(a)

Africa Fixed Broadband Speed test (Mbps)

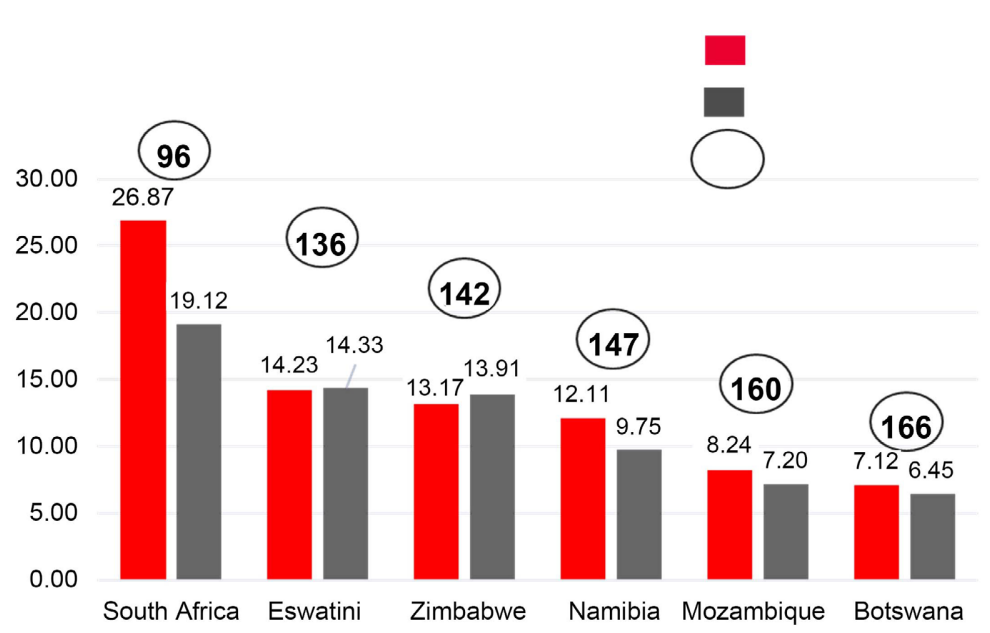

(b)

Figure 7. (a) Global speed test; (b) African speed test. *Data source: OOKLA, Speed test intelligence 2020 . 
The initial addressable market in South Africa was around 3.65 m households (in Figures 8(a)-(d)). Fixed Network Operators (FNOs) are moving beyond the traditional middle-income areas to more highly densely populated areas. The latter increases the addressable market size by approximately 3.5 times. FNOs have amended their business models so that their deployment cost and degree of competition are lower. Furthermore, their customer base is less complex and less demanding. Vumatel is far more aggressive than other operators, and so it has reached $1 \mathrm{M}$ home passes (HPs) in five years.

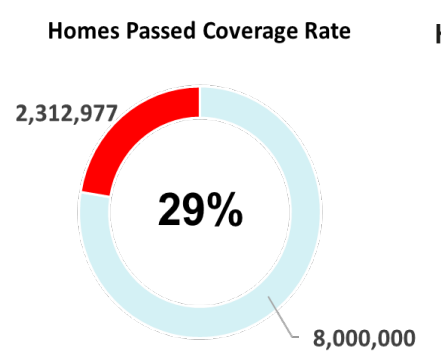

(a)

\section{Homes Connect Penetration Rate}

949,215

$12 \%$

$8,000,000$

(b)

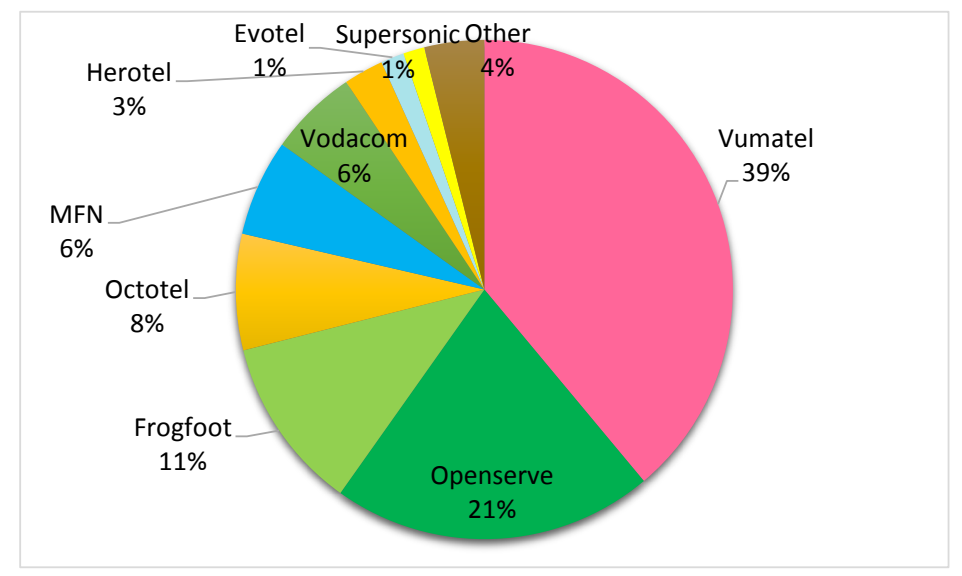

(c)

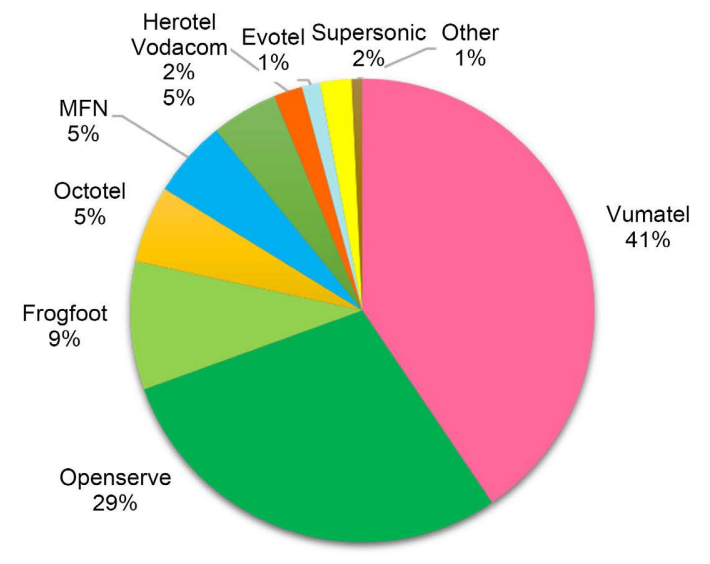

(d)

Figure 8. (a) Homes passed coverage rate; (b) Homes connect coverage rate; (c) Homes passed percentage of SA operators; (d) Homes connect percentage of SA operators. *Source: Market Insight, FNO financial statements \& My Broadband 2021. 
As the two major players in the South African fiber market, Vumatel and Telkom (Openserve/Consumer) will continue to compete extensively. After Vumatel passed SA Telkom to become the largest provider in the South African fiber market, SA Telkom rushed to take back the first-place ranking by competing in coverage and price wars (in Figure 9(a), Figure 9(b)).

\subsection{B Customers (Fixed Network Market)}

The Fiber $2 \mathrm{~B}$ market is extremely similar to the wireless market. Many $2 \mathrm{~B}$ customers use a $2 \mathrm{C}$ package, so some $2 \mathrm{~B}$ customers have been counted as $2 \mathrm{C}$ subscribers. Even in townships, some people buy or rent $2 \mathrm{C}$ packages from operators-either fiber or wireless-over which they drive $2 \mathrm{~B}$ services. Due to security issues in townships, we cannot collect detailed data regarding this practice.

One of COVID-19's impacts on the economy is that more people are working from home, and this in turn has resulted in the following behavioral trends: demand symmetrical bandwidth has increased; the peak periods are no longer from $6 \mathrm{pm}$ to $10 \mathrm{pm}$ but last the entire day, beginning at 9am; and bandwidth utilization has increased from $40 \mathrm{~GB}$ to $400 \mathrm{~GB}$ in two years.

Currently, BCX and SME, subsidiaries of SA Telkom, are aimed at $2 \mathrm{~B}$ customers. SME focuses on small to middle-companies, while BCX aims at big customers. They customized the data/airtime packages for different customers, receiving many orders from companies and South African government departments.

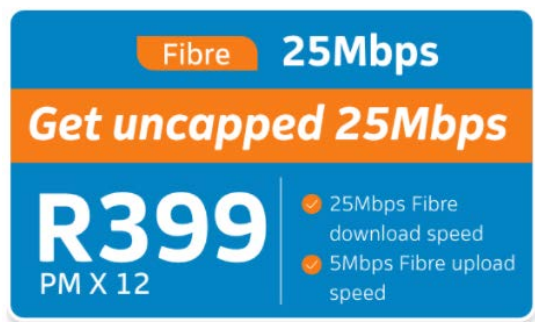

(a)

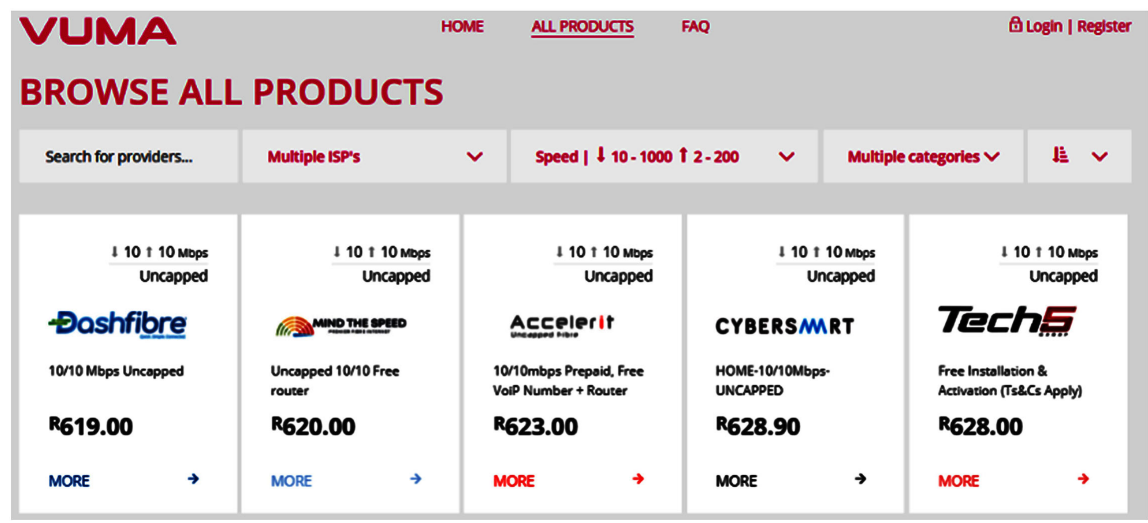

(b)

Figure 9. (a) Telkom offer; (b) Vuma offer. ${ }^{\star}$ Data source: online/offline advertisement of operators. 
From 2013 to 2019, the formal business sector increased turnover from R7.0 trillion to R10.5 trillion (average annual growth rate: 7.0\%) (in Figure 10(a), Figure 10(b)). Medium business increased turnover by $8.4 \%$ per year, and large business by $5.4 \%$.

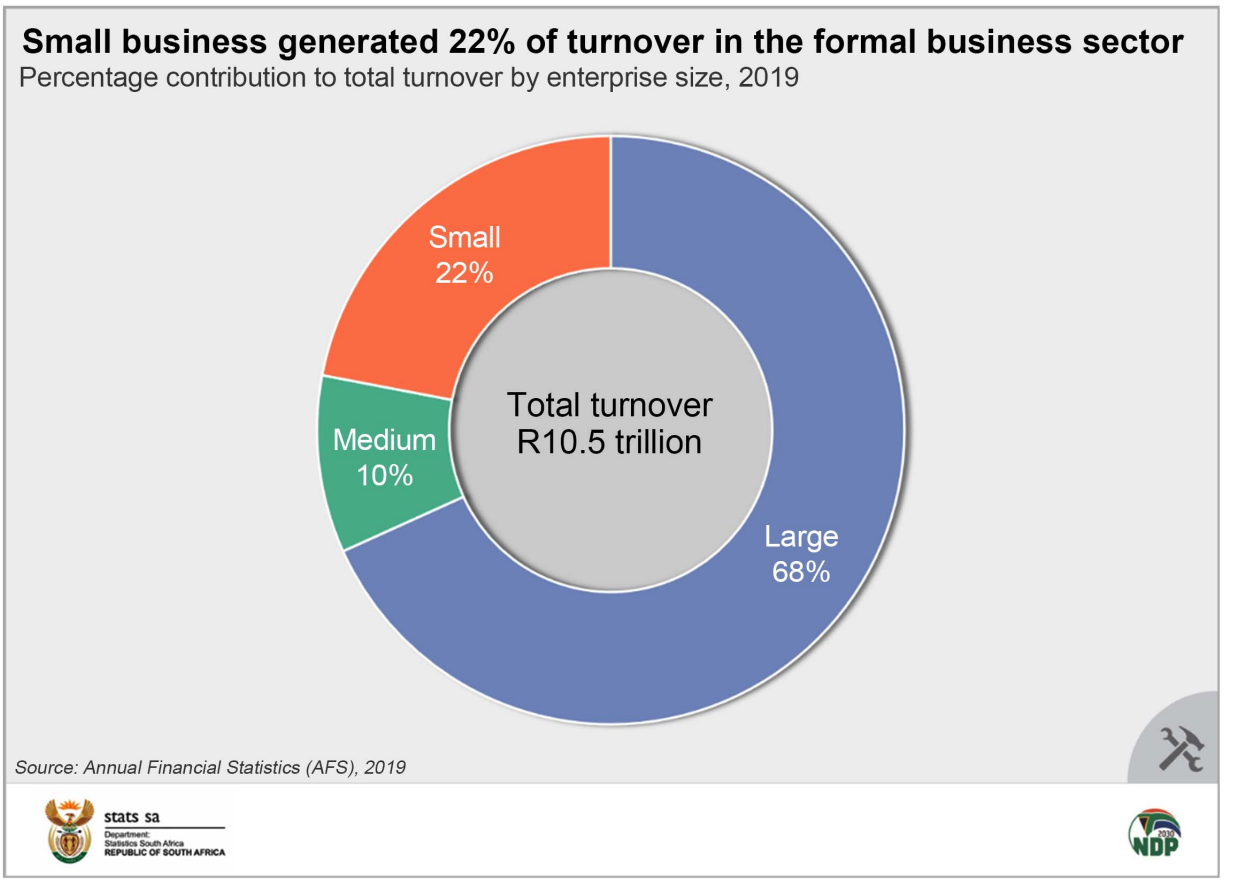

(a)

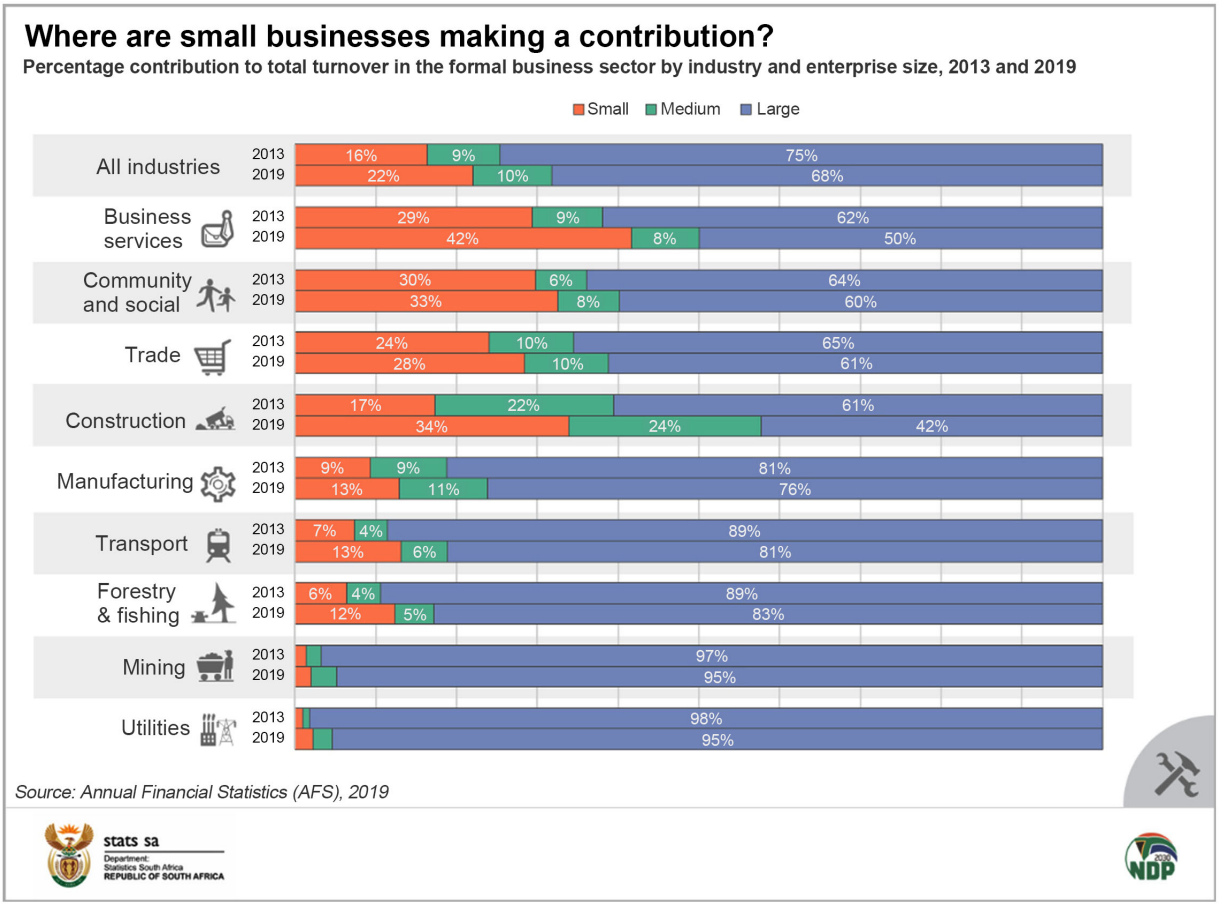

(b)

Figure 10. (a) Small business turnover; (b) Small business contribution. ${ }^{\star}$ Data source: SA Annual financial statistics (AFS) 2019. 
All fixed network operators are still focused on the $2 \mathrm{~B}$ market due to its market growth (in Figure 11(a), Figure 11(b)). Now as a trend, however, the main players of the fiber market are interested in increasing the percentage of pre-paid customers in order to improve revenue and profit.

\subsection{Operators Competition (Fixed Network Market)}

As all operators have felt that the market is transforming, they have begun to aggressively roll out fiber. For example, Vumatel delivered $500 \mathrm{k}$ within a year. Vumatel further grew by acquiring companies such as SADV and Fibrehoods. Vumatel not only used DFA vast network coverage but also rolled out services in territories beyond traditional middle-class neighborhoods. They have expanded into high-density lower-income areas by deploying $\mathrm{O} / \mathrm{H}$ fiber to reduce costs and shorter TTMs. They offer simple prepaid packages to lower-income areas with a limited number of ISPs and monthly top-up options.

\begin{tabular}{|c|c|c|c|}
\hline $25 \mathrm{Mbps}$ & 0Mbos & 0Mbos & $0 \mathrm{Mbos}$ \\
\hline $\begin{array}{l}\text { UnlimitedHomelite } \\
\text { (Uncapped) }\end{array}$ & $\begin{array}{l}\text { UnlimitedHomeLite } \\
\text { (Uncapped) }\end{array}$ & $\begin{array}{l}\text { UnlimitedHomeLite } \\
\text { (Uncapped) }\end{array}$ & $\begin{array}{l}\text { UnlimitedHomeLite } \\
\text { (Uncapped) }\end{array}$ \\
\hline $\begin{array}{l}\text { month to month } \\
\text { 25mbps filbe dounlood speed } \\
\text { 25imbs Filore uplood speed }\end{array}$ & $\begin{array}{l}\text { month to month } \\
\text { sombes filbre downlood speed } \\
25 \text { imbps filore uplood speed }\end{array}$ & $\begin{array}{l}\text { month to month } \\
\text { 100mbps fillore downlood speed } \\
\text { Sombps filbe uplood spoed }\end{array}$ & $\begin{array}{l}\text { month to month } \\
200 \text { Mbps filbe downlood speed } \\
200 \text { mbps Filore uplood speed }\end{array}$ \\
\hline $\begin{array}{l}\text { - } 1 \text { Mallbox (3GB and } 5 \text { allases) } \\
\text { - No Fup thresholds apply. } \\
\text { - } 24 \text {-month contract includes } \\
\text { Installation and router } \\
\text { - Closer Bolt-on Calling Plan } \\
\text { avallable at an additional cost }\end{array}$ & $\begin{array}{l}\text { - } 1 \text { Mallbox (3G8 and } 5 \text { aliases) } \\
\text { - No FuP thresholds apply. } \\
\text { - } 24 \text {-month contract includes } \\
\text { Installation and router } \\
\text { - Closer Bolt-on Calling Plan } \\
\text { avallable ar an additional cost }\end{array}$ & $\begin{array}{l}\text { - I Malbox (3GB and } 5 \text { allases) } \\
\text { - No FUP thresholds apply. } \\
\text { - } 24 \text {-month contract includes } \\
\text { Installation and router } \\
\text { - Closer Bolt-on Calling Plan } \\
\text { awallable ar an additional cost }\end{array}$ & $\begin{array}{l}\text { - I Mallbax (3GB and } 5 \text { aliases) } \\
\text { - No FuP thresholds apply. } \\
\text { - } 24 \cdot \text { month contract includes } \\
\text { Installacion and router } \\
\text { - Closer Bolt-on Calling Plan } \\
\text { avallable at an additional cost }\end{array}$ \\
\hline
\end{tabular}

(a)

\begin{tabular}{|c|c|c|c|c|}
\hline$\frac{150+50 \mathrm{Mbps}}{\text { Uncapped }}$ & $\frac{150+5 \mathrm{Mtps}}{\text { Uncapped }}$ & $\frac{150+5 \mathrm{nbps}}{\text { Uncapped }}$ & $\frac{120+20 \mathrm{mbps}}{\text { Uncapped }}$ & $\frac{150+5 \mathrm{mbps}}{\text { Uncapped }}$ \\
\hline 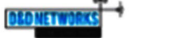 & cooledeas & & rest Net & mweb. \\
\hline $\begin{array}{l}\text { B Froe sarsombps } \\
\text { Uncepped }\end{array}$ & $\begin{array}{l}\text { soMbps Uncapped } \\
\text { SubZero Cool Package.. }\end{array}$ & $\begin{array}{l}\text { SOVSMb FTTH (Fibre to } \\
\text { the Home) }\end{array}$ & $\begin{array}{l}\text { ResiNet FTTH OPV } \\
\text { EXTREME 2Q/2OMDPS }\end{array}$ & $\begin{array}{l}\text { Uncapped * Unchrottiled } \\
\text { - FREE Setup \& Router }\end{array}$ \\
\hline R969.00 & R969.00 & R969.00 & R969.00 & R969.00 \\
\hline MORE & MORE & MORE & MORE & MORE \\
\hline $150+50$ vbos & $150+50 \mathrm{Ntb}$ & $150+5 \mathrm{ubp}$ & $150+5$ Mbps & $150+5 \mathrm{Mbps}$ \\
\hline Uncapped & Capped & Uncapped & Uncapped & Uncapped \\
\hline avFirstinet & VANILLA & & HOME CENNECI & 10 \\
\hline Home sarso Mbps & FTTH - 50/50 * 100GB & $\begin{array}{l}\text { Fibre Fast Uncapped Low } \\
\text { Subs sors Mbps }\end{array}$ & sors fbrevibe Ultimate. & vuma sorsmbps Home \\
\hline R975.00 & R975.00 & R975.00 & R978.00 & R979.00 \\
\hline MORE & MORE & MORE & MORE & MORE \\
\hline
\end{tabular}

(b)

Figure 11. (a) Products of Telkom; (b) Products of VUMA. ${ }^{\star}$ Data source: online/offline advertisement of operators. 


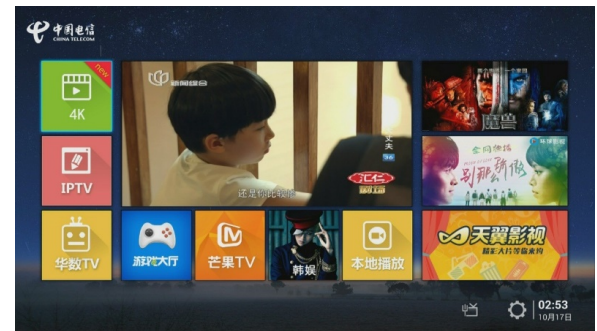

(a)

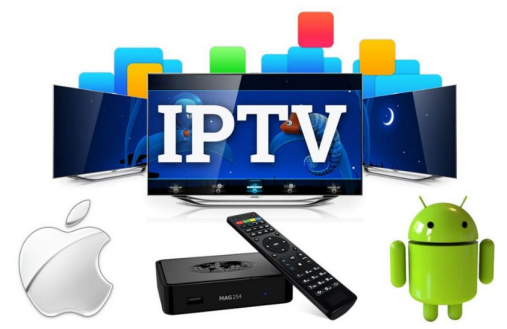

(b)

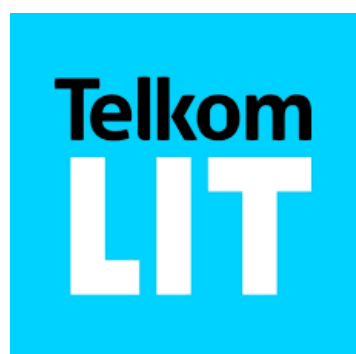

(c)

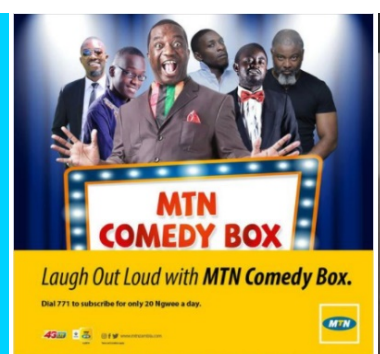

(d)

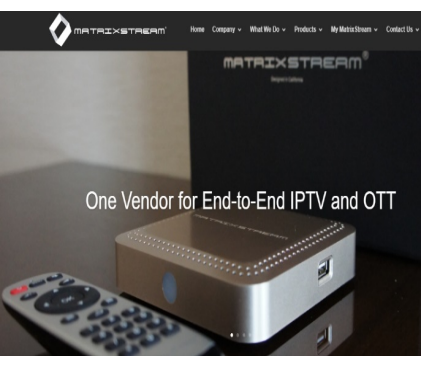

(e)

Figure 12. (a) Products of China Telecom; (b) IPTV; (c) Products of SA Telkom; (d) OTT.

While the ROI of the fiber market is not as good as the wireless market, all fixed network operators have to face issues that stem from heavy asset operation. Thus, the competition in the fiber market is not as tough as the competition in the wireless market. In some European countries (e.g., Romania), wireless operators are required to pay license fees while fixed network operators in those countries do not need to pay for fixed network licenses. For fiber market operators, fiercer competition comes from wireless network operators as opposed to other fixed network operators.

\subsection{New Services Drivers (Fixed Network Market)}

As in the wireless market, video/picture services drive the demand for broadband services (in Figure 12(a)-(d)). For a family subscriber, children typically like cartoons, youth prefer networked games, and adults work from home. Operators are all following the trends that changes in the $21^{\text {st }}$ century bring.

\section{Summary}

In developed European and East Asia countries, strong demand for AI and video streaming services drives the growth of the data market. Both the competition among operators and demands from customers/subscribers reduce the unit prices for airtime and data service even faster. The digital revolution is coming, which will replace traditional services like airtime and data.

$>$ In developing countries such as South Africa, Nigeria, and Kenya, local subscribers enjoy short form videos from Tiktok, YouTube and so on. These videos require an expanded broadband pipeline.

Many governments of both developed and developing nations have invested 
in building fixed and wireless networks that cover entire countries, including the suburbs and rural areas. These new networks enable more people to have to share data for online education and online business (sale and shopping), and so on. The South African government launched South Africa's Broadband Policy on 20th Nov 2013: South Africa Connect, the national broadband policy, and the associated strategy and plan give expression to South Africa's vision in the National Development (NDP) of "a seamless information infrastructure by 2030 that will underpin a dynamic and connected vibrant information society and a knowledge economy that is more inclusive, equitable and prosperous". As envisaged in the NDP, at the core of this will be "a widespread communication system that will be universally accessible across the country at a cost and quality that meets the communication of citizens, business and the public sector and provides access to the creation and consumption of a wide range of converged applications and services required for effective economic and social participation".

\section{Conflicts of Interest}

The author declares no conflicts of interest regarding the publication of this paper.

\section{References}

Data Source: Finance Statement of Operators and Their Online/Offline Advertisement. https://www.telkom.co.za/

https://www.mtn.co.za/

https://www.vodacom.co.za/

https://www.cellc.co.za/

Data Source: OOKLA, Speed Test Intelligence 2020.

Data Source: Operators' AD (Online/Offline)

https://www.telkom.co.za/

https://www.mtn.co.za/

https://www.vodacom.co.za/

https://www.cellc.co.za/

https://vumatel.co.za/

https://congstar.angebote-tarife.de/

https://www.lycamobile.de/en/

https://www.Telecom.de/

https://www.vodafone.de/

http://www.10086.cn/

http://www.chinatelecom.com.cn/

http://www.chinaunicom.com/

Data Source: SA Annual Financial Statistics (AFS) 2019.

http://www.statssa.gov.za/?p=13900

IDC: Others Include Dedicated Internet Access (DIA), Fixed Wireless Access (FWA), and Satellite (VSAT).

Population Amount: The World Bank.

https://data.worldbank.org/indicator/SP.POP.TOTL 
Source: Market Insight, FNO Financial Statements \& My Broadband 2021.

Subscribers Amount: Operator's Finance Report.

https://www.telkom.co.za/ir/financial/financial-results-2018.shtml

https://www.mtn.com/investors/financial-reporting/annual-results/

https://www.vodacom.com/integrated-reports.php 